NASA/TM-2002-211722

IECEC-2002-20023

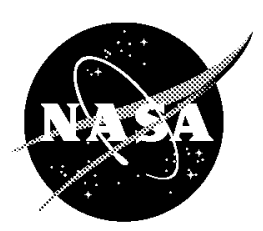

The Evaluation and Implementation of a Water Containment System to Support Aerospace Flywheel Testing

Larry M. Trase

Glenn Research Center, Cleveland, Ohio 
The NASA STI Program Office ... in Profile

Since its founding, NASA has been dedicated to the advancement of aeronautics and space science. The NASA Scientific and Technical Information (STI) Program Office plays a key part in helping NASA maintain this important role.

The NASA STI Program Office is operated by Langley Research Center, the Lead Center for NASA's scientific and technical information. The NASA STI Program Office provides access to the NASA STI Database, the largest collection of aeronautical and space science STI in the world. The Program Office is also NASA's institutional mechanism for disseminating the results of its research and development activities. These results are published by NASA in the NASA STI Report Series, which includes the following report types:

- TECHNICAL PUBLICATION. Reports of completed research or a major significant phase of research that present the results of NASA programs and include extensive data or theoretical analysis. Includes compilations of significant scientific and technical data and information deemed to be of continuing reference value. NASA's counterpart of peerreviewed formal professional papers but has less stringent limitations on manuscript length and extent of graphic presentations.

- TECHNICAL MEMORANDUM. Scientific and technical findings that are preliminary or of specialized interest, e.g., quick release reports, working papers, and bibliographies that contain minimal annotation. Does not contain extensive analysis.

- CONTRACTOR REPORT. Scientific and technical findings by NASA-sponsored contractors and grantees.
- CONFERENCE PUBLICATION. Collected papers from scientific and technical conferences, symposia, seminars, or other meetings sponsored or cosponsored by NASA.

- SPECIAL PUBLICATION. Scientific, technical, or historical information from NASA programs, projects, and missions, often concerned with subjects having substantial public interest.

- TECHNICAL TRANSLATION. Englishlanguage translations of foreign scientific and technical material pertinent to NASA's mission.

Specialized services that complement the STI Program Office's diverse offerings include creating custom thesauri, building customized data bases, organizing and publishing research results... even providing videos.

For more information about the NASA STI Program Office, see the following:

- Access the NASA STI Program Home Page at http://wwo.sti.nasa.gov

- E-mail your question via the Internet to help@stinasa.gov

- Fax your question to the NASA Access Help Desk at 301-621-0134

- Telephone the NASA Access Help Desk at 301-621-0390

- Write to: NASA Access Help Desk NASA Center for AeroSpace Information 7121 Standard Drive Hanover, MD 21076 
NASA/TM-2002-211722

IECEC-2002-20023

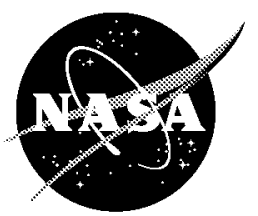

\section{The Evaluation and Implementation of a Water Containment System to Support Aerospace Flywheel Testing}

Larry $M$. Trase

Glenn Research Center, Cleveland, Ohio

Prepared for the

37th Intersociety Energy Conversion Engineering Conference

sponsored by the Institute of Electrical and Electronics Engineers, Electron Devices Society

Washington, DC, July 28-August 2, 2002

National Aeronautics and

Space Administration

Glenn Research Center

July 2002 
Available from

NASA Center for Aerospace Information 7121 Standard Drive

Hanover, MD 21076
National Technical Information Service 5285 Port Royal Road Springfield, VA 22100

Available electronically at hite//gltrs.grcnasagov/CLTRS 


\title{
The Evaluation and Implementation of a Water Containment System to Support Aerospace Flywheel Testing
}

\author{
Larry M. Trase \\ National Aeronautics and Space Administration \\ Glenn Research Center \\ Cleveland, Ohio 44135 \\ Ph.: 216-433-5347 \\ Fax: $216-433-8410$ \\ E-mail: larum.trase ororonasa.gov
}

\begin{abstract}
High-energy flywheel systems for aerospace power storage and attitude control applications are being developed because of the potential for increasing the energy density and reducing operational costs. A significant challenge facing the development of the test hardware is containment of the rotating elements in the event of a failure during the development and qualification stages of testing. This containment is critical in order to ensure the safety of the test personnel and the facility. A containment system utilizing water as the containment media is presented. Water containment was found to be a low cost, flexible, and highly effective containment system. Ballistic test results and analytical results are discussed along with a description of a flywheel test facility that was designed and built utilizing the water containment system at the NASA Glenn Research Center at Lewis Field in Cleveland, Ohio.
\end{abstract}

\section{INTRODUCTION}

The High Energy Flywheel Facility (HEFF) located in the Power Systems Facility (PSF) at the NASA Glenn Research Center in Cleveland, Ohio will be used to demonstrate a single axis attitude control and energy storage system utilizing flywheels. The facility will also be used to test prototype electronics and control algorithms for proposed flywheel energy storage systems for the International Space Station (ISS) and other satellite systems.

The hardware configuration for the experiment will consist of two flywheel modules with parallel spin axis vertically mounted on an air-bearing table. The electronics and controls to support the magnetic bearing and motor/generator systems and provide overall system control are a combination of commercial of the shelf and brass board hardware with rapid prototype software.
Each flywheel module stores $350 \mathrm{~W}$-hrs of electrical energy. The rotor is suspended with active magnetic bearings and has a rolling element touchdown bearing for off nominal conditions. The flywheel module housing provides the vacuum enclosure and mounting locations for the stator components.

The flywheel testing has three objectives: demonstrate two flywheel modules operating on a lightly constrained mounting system (air table), demonstrate a momentum and energy control in charge mode with the flywheels on separate power buses, and finally demonstrate full momentum and energy control in charge and discharge modes on a single power bus. (Kascak, 2002)

The operational demonstration of a magnetically suspended flywheel module functioning on an air table will be used to verify an analytical modeling effort which is exploring the effect of mount stiffness on magnetic bearing stability.

In the second phase of the testing the combined charge rate of and net torque of the two flywheel modules will be controlled. This demonstration will be limited to charge mode only, since the flywheels are operated on separate power buses. Step response, overshoot and regulation band will be compared to analytical models.

Both flywheel modules will be run on one power bus in the final phase of the testing. Charge mode will operate in the same manner as in the second phase. In discharge the controller will regulate the bus voltage and the net torque of the two-wheel system.

All of this testing will be conducted using first generation flywheel modules. The flywheel modules do not have any containment, the housing only provides a vacuum environment for the rotating 
elements. To insure the safety of personnel and facilities these flywheels will require containment in the event of a rotor failure at high speed. This paper summarizes the work that has been completed to provide effective containment for flywheel systems.

\section{CONTAINMENT}

The primary hazard in testing flywheels is a rotor burst at high speed. The rotor is constructed with rings of carbon fiber filaments bound with epoxy. The rotors are wound in layers. These layers form rings and provide a method of reducing the energy release in the event of a rotor failure. In an overstressed condition, the outer ring will separate first. If a failure would occur, only the outer ring would fail and the energy contained in the outer ring, while significant, is not nearly the energy available in the entire rotor. If an overspeed event were to occur, just the outer ring would potentially fail and stop the test.

The flywheel rotor is suspended via active magnetic bearings. The feedback sensors constantly monitor the position of the rotating shaft. Currently, the test operator monitors the shaft position for any long-term deviations or trends. In the future this capability will be added to the magnetic bearing controls to enable the rotor performance and status to be monitored automatically.

The traditional method of containment for rotating hardware is several inches of steel. Spin pits are large, extremely heavy steel chambers typically with several rings of steel surrounding an inner burst liner. This inner burst liner is sometimes lined with lead bricks to preserve fragments. Also the burst liner has a lip around the top to redirect any fragments that are directed vertically up after a failure. This failure mode is of particular concern for the composite flywheels. The composite can be redirected by the burst liner and introduce significant vertical forces.

The challenges of containing the total energy in one flywheel are considerable, however when faced with the requirement to test multiple flywheels as a system, the use of traditional containment becomes impractical. This fact lead to the investigation of other containment methods and water was selected as an effective alternative.

Water containment for explosives safety has been investigated by the military and has been found to be an effective means of suppressing ordnance detonations and reducing the stay clear zones for the storage of explosives. (Malver, 1998)

The effectiveness of water for explosive suppression has been demonstrated by military testing. A number of factors have been presented regarding the effectiveness of water for suppression. One factor is the drag forces are much higher than that of air since the density of water is 800 times that of air. (Salter, 1994; Karplus, 1964)

A second factor may be the bulk modulus of water being so much above that of air that just after an event the water pressure on the outside of a fragment can rise very quickly leaving a smaller pressure gradient across it. In addition due to the latent heat of water, a considerable amount of energy is absorbed as the water is turned into steam at the time of impact. (Salter, 1994; Karplus, 1964)

\section{ANALYSIS}

The flywheel consists of a titanium inner hub wrapped by several separate layers, or rings. Each ring consists of a composite made up of carbon fibers wound in an epoxy matrix. The outer ing is the most highly stressed, and in the event of a failure is designed to separate from the next ring. For this analysis, the kinetic energy contained in the outer ring is given by:

$\begin{array}{ll}\text { Flywheel operational speed: } & \omega=60,000 \mathrm{rpm} \\ \text { or } 6283 \mathrm{rad} / \mathrm{sec} & \\ \begin{array}{l}\text { Composite material density: } \\ \left(0.0595 \mathrm{lb} / \mathrm{in}^{3}\right)\end{array} & \rho=1647 \mathrm{~kg} / \mathrm{m}^{3},\end{array}$

Composite outer ring dimensions:

$0.2358 \mathrm{~m},\left(9.283\right.$ ") OD, radius $\left(\mathrm{r}_{\mathrm{o}}\right)=0.1179 \mathrm{~m}$

$0.2256 \mathrm{~m},\left(8.883^{\prime \prime}\right) \mathrm{ID}$, radius $\left(\mathrm{r}_{\mathrm{i}}\right)=0.1077 \mathrm{~m}$

Height $(h)=0.133 m,(5.25 ")$

Polar moment of inertia:

$$
\begin{gathered}
\left.I=1 / 2 \pi h \rho\left(\left(r_{0}\right)^{4}-\left(r_{i}\right)^{4}\right)\right) \\
\left.I=1 / 2(3.1416)(0.133)(1647)(0.1179)^{4}-(0.1077)^{4}\right) \\
I=0.0202 m^{4}
\end{gathered}
$$

Kinetic energy of outer ring:

$$
\begin{gathered}
\mathrm{KE}=1 / 2 \mathrm{I} \omega^{2} \\
\mathrm{KE}=1 / 2(0.0202)(6283)^{2} \\
\mathrm{KE}=3.99 \times 10^{5} \mathrm{~J}
\end{gathered}
$$

For comparison purposes, $0.454 \mathrm{~kg}(1 \mathrm{lb})$ of TNT generates $2.1 \times 10^{6} \mathrm{~J}$ of energy, i.e., the outer ring contains approximately the same energy as 0.1 $\mathrm{kg}(0.2 \mathrm{lb})$ of TNT, with a maximum fragment velocity due to rotation of $740 \mathrm{~m} / \mathrm{sec}(2430 \mathrm{ft} / \mathrm{sec})$.

An analysis of the motion of a fragment in water was completed determining that the energy vs. distance curve for a fragment of size $L$ can be represented by

$$
E=E_{o} \varepsilon^{-d / L} \quad \text { (Sandler, 1998) }
$$

Where $E_{0}=$ the initial kinetic energy of the fragment, $E$ is the remaining energy, and $d$ is the distance traveled in water.

Plots of this equation with several fragment lengths are shown in Figure 1. 


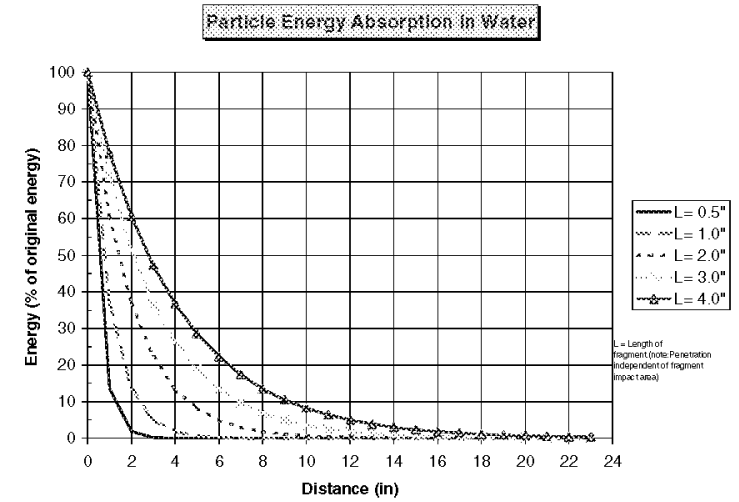

FIGURE 1: ENERGY ABSORPTION IN WATER

By graphing the particle energy vs. distance traveled in water it may be noted that particles that can reasonably be expected to be generated by an outer ring failure lose at least $95 \%$ of their energy by traveling through $0.3 \mathrm{~m}$ (12 in) of water, and virtually all their energy in less than $0.6 \mathrm{~m}$ (24 in) of water.

\section{TESTING}

Limited fragment impact testing was performed in the Ballistics Impact Lab located at the NASA Glenn Research Center. Several fragments were shot into pools of water and filmed with high-speed photography. The fragment size was approximately $2.5 \times 2.5 \times 1.0 \mathrm{~cm}(1.0 \times 1.0 \times 0.325 \mathrm{in})$ and fired with a velocity of approximately $730 \mathrm{~m} / \mathrm{s}(2400 \mathrm{fps})$. Two fragments were fired into water and the fragments were stopped within $30.5 \mathrm{~cm}$ (12 in).

Several methods of holding the water were considered and after an examination of commercially available water containers, a water bladder within a strong cardboard carton was selected. See Figure 3. The water bladder size is approximately $.28 \times .28 \times$ $.28 \mathrm{~m}(11 \times 11 \times 11 \mathrm{in})$ and the overall size is a cube $.29 \mathrm{~m}$ (11.5 in) on each side. Each container holds 5 gallons of water.

Using these containers allows a containment of any suitable size to be easily constructed using the containers as "building blocks". Two rows of containers will be utilized, providing a minimum of $0.56 \mathrm{~m}$ (22 in) of water in the path of any fragments. The containers in the outer wall of the containment will be horizontally and vertically offset from the containers in the inner wall by one half the width of the containers. A cross section of the stacking is shown in Figure 2

A series of tests was conducted to investigate the ability of the water-filled containers to absorb the energy of high-speed projectiles. For the first three tests, the setup was the same. Two containers were filled with water and placed together. A series of

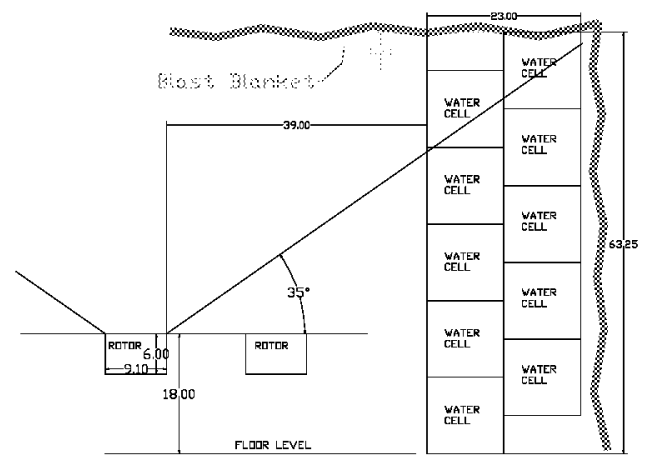

FIGURE 2: CONTAINER STACKING PROFILE

witness plates was placed behind the containers as in figure 3 . Each witness plate was a sheet of $3 / 16$ " luan plywood, and the sheets were placed approximately 1 inch apart. Any particles that were not stopped by the water would impact these witness plates, and a rough evaluation of their remaining energy could be made.

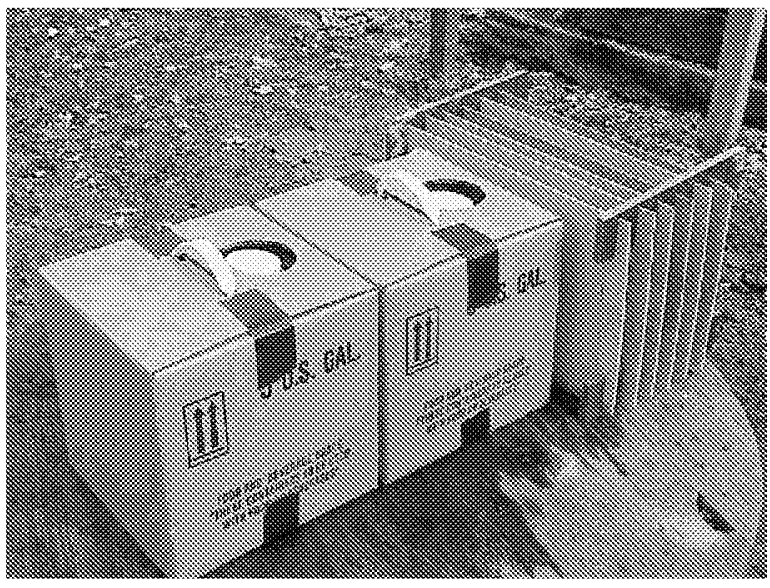

FIGURE 3: CONTAINER TEST CONFIGURATION

\section{TEST \#1}

A 30 -caliber rifle was used to fire a 150 -grain (9.7 g) bullet at approximately $2600 \mathrm{ft} / \mathrm{sec}(790 \mathrm{~m} / \mathrm{sec})$ into the first container. Bullets consist of very dense materials, and are designed to penetrate, being streamlined and spin-stabilized, and thus represent a rather severe test of the absorption capability of any medium.

For this test, a blunt bullet was fired, to more closely approximate an irregularly shaped fragment that would be generated by a flywheel failure. The bullet used a lead core surrounded by a copper jacket. 
In this test the bullet was completely stopped by the first container, i.e., in less than $.28 \mathrm{~m}$ (11 in) of water. The bullet was intact, but deformed and expanded to approximately twice its original diameter. The container was completely split open and the water was widely dispersed.

\section{TESTS \#2 and \#3}

A 12-gauge shotgun was used to fire a magnum 00 buckshot cartridge into the first container. This cartridge was comprised of 15 lead balls, each weighing $3.2 \mathrm{~g}$ (50 grains), for a total projectile weight of $48 \mathrm{~g}$ (750 grains). Velocity was approximately 430 $\mathrm{m} / \mathrm{sec}(1400 \mathrm{ft} / \mathrm{sec})$. Shot patterns tend to 'string out' into a fairly long patterns, thus many projectiles will travel in the wake of the leading projectiles as they impact the water. The first projectiles that hit will begin to disperse the water, and later projectiles will encounter less resistance as they will be traveling in a liquid/vapor mix, rather than the all-liquid state the leading projectiles will encounter.

As a result, most projectiles (13 in test \#2, 14 in test \#3) completely penetrated the first container, and entered the second. The container was simply pierced, and was not split open like the much higher velocity rifle bullet in test \#1.

In test \#2, 8 of 13 projectiles reached the back of the second container and made marks on the first witness plate, which had become pressed against the container by the dynamics of the impact. Several of these projectiles were actually stopped by the rear cardboard wall of the second container as it pressed on the witness plate, and thus possessed essentially zero energy. A single projectile penetrated the first witness plate, and was stopped by the second witness plate barely leaving a mark.

In test \#3, 10 of 14 projectiles reached the rear wall of the second container. Two penetrated the first witness plate. None damaged the second witness plate.

\section{TEST \#4}

For this test, actual samples of carbon fiber matrix from a scrap flywheel were fired from GRC's Ballistic Impact Facility into an array of containers. Two samples approximately $12 \times 19 \times 25 \mathrm{~mm}(1 / 2 " \times$ $3 / 4$ " $\times 1$ ") weighing $12 \mathrm{~g}$ and one sample $12 \times 19 \times$ $50 \mathrm{~mm}(1 / 2 " \times 3 / 4 " \times 2 ")$ weighing $25 \mathrm{~g}$ were placed such that their long axis was aligned with the direction of firing. Velocity obtained was $700 \mathrm{~m} / \mathrm{sec}(2300 \mathrm{ft} / \mathrm{sec})$. One container was placed forward for the samples to impact, and 4 others were placed behind it, offset horizontally and vertically by one half the width of a container.

Recovered samples indicate that the carbon fiber matrix broke up into small fragments upon impact with the water. The largest recovered piece was approximately $3 \mathrm{~g}$ while most were much smaller. Total mass of the recovered fragments that were significant in size was $6.7 \mathrm{~g}$. The remainder was comprised of small pieces of fiber strewn throughout the first container and surrounding area.
The forward container had been rotated clockwise during the test. This was a consequence of not being firmly tied in place, and the large air blast that results from the operation of this facility. This allowed some particles to exit the left side of the container (which was now facing backwards) after traveling only a short distance through the water, perhaps $150 \mathrm{~mm}$ ( $6 \mathrm{in}$ ). The large recovered fragment penetrated one rear container. Most of the smaller fragments stuck in the cardboard of the rear containers and did not penetrate into the water.

\section{FACILITY DESCRIPTION}

The requirements for HEFF were to have the capability to test two flywheel modules simultaneously. The room in which the HEFF is located is constructed of 12" thick, reinforced concrete walls on 5 sides. The outside wall is designed as a blow out wall in the event of an overpressure in the room. This room is being used as secondary containment for the test. The primary containment media being used is water. Approximately 250 cardboard boxes containing plastic bladders that hold approximately $1 \mathrm{ft}^{3}$ of water each will surround the airbearing platform. Figure 4 shows a plan view showing the containers placement around the test articles.

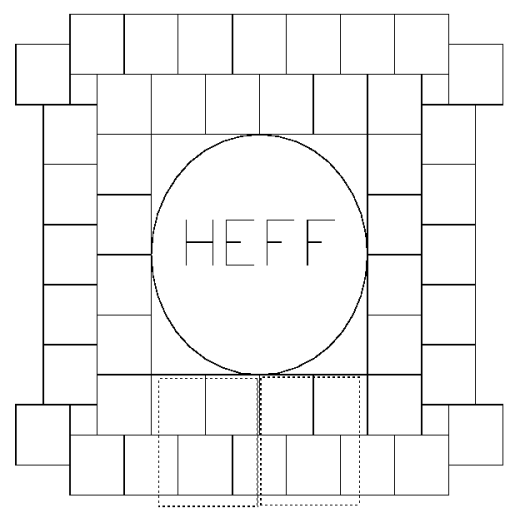

FIGURE 4: TEST FACILITY PLAN VIEW

As a redundant layer of protection, the entire containment assembly will be covered on 5 faces (the 4 sides and the top) by a commercial bomb blanket designed to suppress both blast and fragments.

\section{CONCLUSIONS}

This paper has described a method to provide containment for the testing of high-speed energy storing flywheels. This method utilizes inexpensive cardboard water containers filled with water and stacked around the flywheels to be tested. The method has been shown to be flexible yet effective. Analysis has shown that the majority of fragment energy will be absorbed by the initial $0.3 \mathrm{~m}$ (12 in) of water. Performing testing that included firing fragments and bullets into containers of water has supported the analysis. Covering the entire 
configuration with a fragment blanket and locating the facility inside a blast room provides secondary and tertiary levels of containment.

\section{REFERENCES}

Kascak, P.E., and Jansen, R.H., "Single Axis Attitude Control and DC Bus Regulation With Two Flywheels," Paper \#20078,To be Published IECEC, Washington, DC, July 2002.

Malver, L.J., and Tancreto, J.E., $28^{\text {th }}$ DDESB Seminar, Orlando, FL, August 1998.
Salter, S.H., and Parkes, J.H., "The Use of Water Filled Bags to Reduce the Effect of Explosions," DoD Explosives Safety Seminar, Miami, August 1994.

Karplus, H.B., and Clinch, J.M., "Sound Propagation in Two-phase Fluids," Journal of the Acoustical Society of America, Vol. 36, p. 1040, 1964.

Sandler, I.S., "Analysis of the Effects of Flywheel Breakup for Determining Design Specifications for a Water-Filled Test Facility," Final Report for NASA Lewis Research Center, Contract C-75128-1, December 1998. 


\begin{tabular}{|c|c|c|}
\hline \multicolumn{2}{|c|}{ REPORT DOCUMENTATION PAGE } & $\begin{array}{l}\text { Form Approved } \\
\text { OMB No. } 0704-0188\end{array}$ \\
\hline \multicolumn{3}{|c|}{ 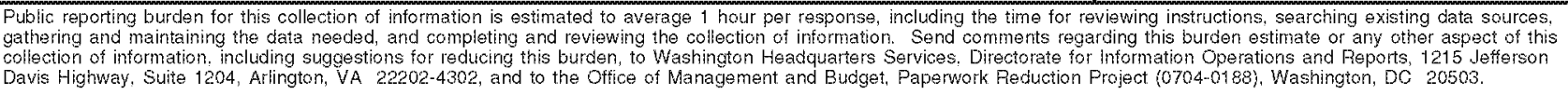 } \\
\hline i. AGENCY USE ONLY (Leave blank) & $\begin{array}{r}\text { 2. REPORT DATE } \\
\text { July } 2002\end{array}$ & $\begin{array}{l}\text { D DATES COVERED } \\
\text { echnical Memorandum }\end{array}$ \\
\hline \multicolumn{2}{|c|}{$\begin{array}{l}\text { 4. TITLE AND SUBTITLE } \\
\text { The Evaluation and Implementation of a Water Containment System to } \\
\text { Support Aerospace Flywheel Testing }\end{array}$} & \multirow{2}{*}{$\begin{array}{l}\text { 5. FUNDING NUMBERS } \\
\text { WU-755-1A-09-00 }\end{array}$} \\
\hline \multicolumn{2}{|l|}{$\begin{array}{l}\text { 6. A.UTHOR(S) } \\
\text { Latry M. Trase }\end{array}$} & \\
\hline \multicolumn{2}{|c|}{$\begin{array}{l}\text { 7. PERFORMING ORGANIZATION NAME(S) AND ADDRESS(ES) } \\
\text { National Aeronautics and Space Administration } \\
\text { John H. Glemn Research Center at Lewis Field } \\
\text { Cleveland, Ohio } 44135-3191\end{array}$} & $\begin{array}{l}\text { 8. PERFORMING ORGANIZATION } \\
\text { REPORT NUMBER } \\
\text { E-13473 }\end{array}$ \\
\hline $\begin{array}{l}\text { 9. SPONSORING/MONITORING AGEN } \\
\text { National Aeronautics and Sp } \\
\text { Washington, DC 20546-00 }\end{array}$ & $\begin{array}{l}\text { NAME(S) AND ADORESS(ES) } \\
\text { Administration }\end{array}$ & $\begin{array}{l}\text { 10. SPONSORING/MONITORING } \\
\text { AGENCY REPORT NUMBER } \\
\text { NASA TM-2002-211722 } \\
\text { IECEC-2002--20023 }\end{array}$ \\
\hline
\end{tabular}

Prepared for the 37th Intersociety Energy Conversion Engineering Conference sponsored by the Institute of Electrical and Electronics Engineers, Electron Devices Society, Washington, DC, July 28-August 2, 2002. Responsible person, Larry M. Trase, organization code 7550, 216-433-5347.

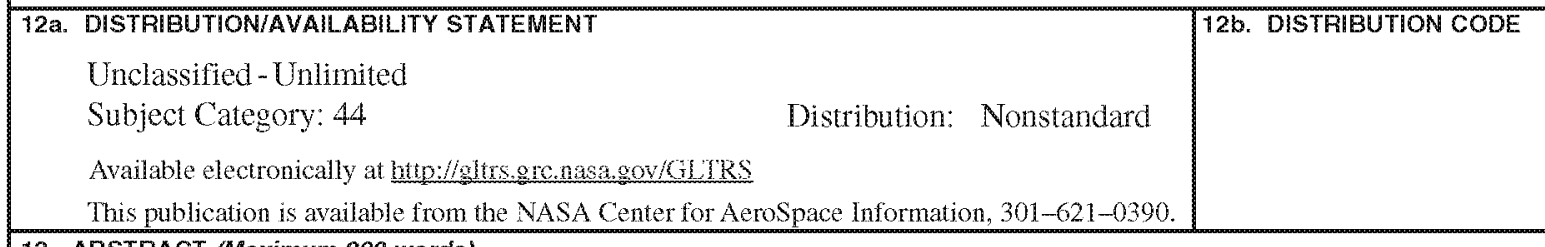

13. ABSTRACT (Maximum 200 words)

High-energy flywheel systems for aerospace power storage and attitude control applications are being developed because of the potential for increasing the energy density and reducing operational costs. A significant challenge facing the development of the test hardware is containment of the rotating elements in the event of a failure during the development and qualification stages of testing. This containment is critical in order to ensure the safety of the test personnel and the facility. A containment system utilizing water as the containment media is presented. Water containment was found to be a low cost, flexible, and highly effective containment system. Ballistic test results and analytical results are discussed along with a description of a flywheel test facility that was designed and built utilizing the water containment system at the NASA Glem Research Center at Lewis Field in Cleveland, Ohio.

\begin{tabular}{|c|c|c|c|}
\hline \multirow{2}{*}{\multicolumn{3}{|c|}{$\begin{array}{l}\text { 14. SUBJECT TERMS } \\
\text { Test facilities; Safety; Flywheels; Containment }\end{array}$}} & \multirow{3}{*}{$\begin{array}{l}\text { 15. NUMBER OF PAGES } \\
111 \\
\text { 16. PRICE CODE } \\
\text { 20. LIMITATION OF ABSTRACT }\end{array}$} \\
\hline & & & \\
\hline $\begin{array}{l}\text { 17. SECURITY CLASSIFICATION } \\
\text { OF REPORT } \\
\text { Unclassified }\end{array}$ & $\begin{array}{l}\text { 18. SECURITY CLASSIFICATION } \\
\text { OF THIS PAGE } \\
\text { Unclassified }\end{array}$ & $\begin{array}{l}\text { 19. SECURITY CLASSIFICATION } \\
\text { OF ABSTRACT } \\
\text { Unclassified }\end{array}$ & \\
\hline NSN $7540-01-280-5500$ & & & $\begin{array}{l}\text { Indard Form } 298 \text { (Rev. 2-89) } \\
\text { scribed by ANSI Std. Z39-18 } \\
-102\end{array}$ \\
\hline
\end{tabular}

